\title{
SISTEM OLAHRAGA PRESTASI DI INDONESIA DAN CHINA
}

\author{
Eka Purnama Indah \\ Universitas Lambung Mangkurat \\ eka.indah@ulm.ac.id
}

\begin{abstract}
ABSTRAK
Penelitian ini bertujuan untuk membandingkan perkembangan sistem olahraga prestasi yang dilakukan di Indonesia dan China dalam rangka peningkatan kualitas olahraga. Penelitian ini menggunakan metode deskriptif kualitatif dengan teknik pengumpulan data melalui studi dokumentasi. Hasil penelitian ini menyimpulkan bahwa diperlukan kontribusi pemerintah dalam mempersiapkan srategi pemenangan, fasilitas latihan, menambah peluang kompetisi dan peningkatan sumber daya yang bisa dibantu oleh tim akademisi dan peneliti dari universitas untuk menemukan teknik-teknik baru dalam pelatihan untuk menunjang pemanfaatan sport science secara maksimal.
\end{abstract}

Kata Kunci: Sistem Olahraga Prestasi, Indonesia, China

\section{COMPETITIVE SPORT SYSTEM IN INDONESIA AND CHINA}

\begin{abstract}
This study aims to compare the competitive sport system development in Indonesia and China, in the context of improving sports quality. This study use the deskriptif qualitatif method with the document study to collect the data.The results are as follows that the government contribution is needed in preparing the winning strategy, training facility, increase the competition opportunities and increased resources that can be helped by a team of academics and researchers from university to find the new techniques in training to support the maximum use of sport science.
\end{abstract}

Keywords: Competitive Sport System, Indonesia, China

Dipublikasikan Oleh :

UPT Publikasi dan Pengelolaan Jurnal

Universitas Islam Kalimantan Muhammad Arsyad Al-Banjari Banjarmasin 


\section{PENDAHULUAN}

Olahraga sebagai salah satu model karya cipta manusia, merupakan suatu bentuk aktivitas fisik yang memiliki dimensi sangat kompleks, yang mengalami proses sistematik berupa segala kegiatan atau usaha yang dapat mendorong, membangkitkan, mengembangkan dan membina potensi-potensi jasmaniah dan rohaniah seseorang sebagai perorangan atau anggota masyarakat dalam bentuk permainan, perlombaan/ pertandingan, dan kegiatan jasmani yang intensif untuk memperoleh rekreasi, kemenangan, dan potensi puncak dalam rangka pembentukan manusia Indonesia seutuhnya yang berkualitas berdasarkan Pancasila (Cholik, 2002, p. 152).

Kegiatan olahraga disetiap negara pada prinsipnya sama yakni digunakan untuk memenuhi kebutuhan praktis dalam kehidupan karena memiliki daya tarik untuk mengembangkan berbagai kemampuan, menumbuhkan harapan, memberikan pengalaman pengembangan, meningkatkan kesegaran jasmani dengan mengikut sertakan sistem otot-otot yang dihasilkan sampai kepada ikut sertaan dalam kegiatan olahraga.

Salah satu fokus negara Indonesia dalam perkembangan kegiatan olahraga yakni olahraga prestasi. Dewasa ini bangsa Indonesia berada dalam masa reformasi menuju berbagai perubahan penting dalam penyelenggaraan negara serta menata kembali berbagai sektor pembangunan agar dapat berhasil keluar dari krisis yang berkepanjangan. Bahkan krisis yang terjadi mengakibatkan Indonesia jauh tertinggal dengan negara-negara di kawasan Asia meskipun sudah memiliki sistem olahraga yang diterapkan.

Masih dalam ingatan kita bahwa pada Olimpiade 2008 di Beijing, Siapakah yang menjadi juara umum pada saat itu? Ya, Memang tidak ada yang pernah menyangka bahwa China hampir menyapu bersih semua medali emas yang diperebutkan di setiap cabang olahraga yang dipertandingkan pada Olimpiade tersebut, walaupun di bawah bayang-bayang juara bertahan amerika serikat. Sebenarnya, apa yang telah dilakukan oleh pemerintah China dalam mempersiapkan atletnya melalui kebijakan-kebijakan dalam praktik olahraga yang berlangsung terus-menerus dari tahun 1920-an hingga 2000-an dengan penekanan khusus pada Olimpiade Beijing (Wei, Hong, \& Zhouxiang, 2010, p. 2380-2402).

Untuk menghadapi pesta olahraga terbesar di dunia itu dipersiapkan melalui proses yang panjang dengan menggabungkan beberapa bidang yakni bidang pendidikan, ekonomi, sosial, industri, dan secara spesifik meliputi ilmu keolahragaan, fasilitas, peralatan, dan kedokteran olahraga. Bahkan bidang pendidikan dan olahraga di China berada dalam satu departemen sehingga terpusat dan terkendali dalam satu pengawasan.

Pembangunan nasional melalui pengembangan olahraga di Indonesia pada era reformasi ini menjadi wahana yang strategis, khususnya peningkatan kualitas SDM, serta pembentukan watak dan karakter bangsa. Salah satu bentuk nyata perkembangan olahraga secara nasional di era reformasi adalah telah disahkannya sekaligus diundangkannya Undang-Undang No. 3 Tahun 2005 tentang Sistem Keolahragaan Nasional pada tanggal 23 September 2005. Penetapan hukum olahraga nasional ini membawa angin segar sekaligus arah pembangunan olahraga yang jelas, terstruktur, terkoordinasi dan mendapatkan kepastian hukum secara nasional. Penetapan hukum olahraga nasional disamping memberikan peluang atau prospek, juga memberikan tantangan yang tidak ringan dalam pembangunan olahraga secara nasional. Hal ini karena persoalan olahraga telah berkembang begitu kompleks, sarat nuansa persaingan hingga politik, dan jika tak terkelola secara sistematik dapat mengarah ke sisi yang berlawanan dari tujuan utamanya.

Berdasarkan uraian di atas bahwa banyak faktor yang berperan dalam kesuksesan dibidang olahraga, salah satunya disini penulis ingin mengkaji perbedaan dan persamaan sistem olahraga prestasi antara yang berjalan di Indonesia dan China. Perbedaan disini bukan berarti untuk mencari siapa yang lebih baik akan tetapi dapat dijadikan bahan kajian dan informasi dalam pengembangan olahraga kedepannya.

\section{METODE}

Jenis penelitian ini adalah penelitian komparasi dengan metode penelitian deskriptif kualitatif yang bertujuan untuk menemukan persamaan-persamaan dan perbedaan-perbedaan tentang benda, orang, ide, prosedur kerja terhadap orang, kelompok atau negara (Arikunto, 2010, p. 310). Penelitian ini menitikberatkan pada kesamaan-kesamaan dan perbedaan-perbedaan negara Indonesia dan China dalam pemahaman, pandangan dan pelaksanaan sistem olahraga prestasi.

Subjek penelitian dalam penelitian komparasi ini adalah sistem olahraga prestasi yang dilaksanakan di negara Indonesia dan China.

Dipublikasikan Oleh : 
Data yang digunakan dalam penelitian ini adalah sumber dokumen, dengan teknik pengumpulan data yang dilakukan pada subjek penelitian melalui studi dokumentasi dengan pemanfaatan sekumpulan arsip, yang diungkapkan oleh Shodiq \& Muttaqien dalam Strauss \& Corbin (Shodiq \& Muttaqien, 2003, p. 212). Teknik analisis data dilakukan dengan metode arsip analitis sehingga memudahkan dalam penelusuran informasi maupun pikiran (Alwasilah, 2003, p. 165).

\section{HASIL DAN PEMBAHASAN}

Olahraga prestasi akan terus berkembang dalam bentuk tradisional 'Juguo Tizhi' dimana seluruh negara mendukung sistem olahraga prestasi untuk tujuan politik dan patriotiknya (Wei, Hong, \& Zhouxiang, 2010, p. 2380-2404). Berikut perbandingan antara olahraga prestasi di Indonesia dan China disajikan dalam tabel 1.

Tabel 1. Perbandingan Sistem Olahraga Prestasi di Indonesia dan China

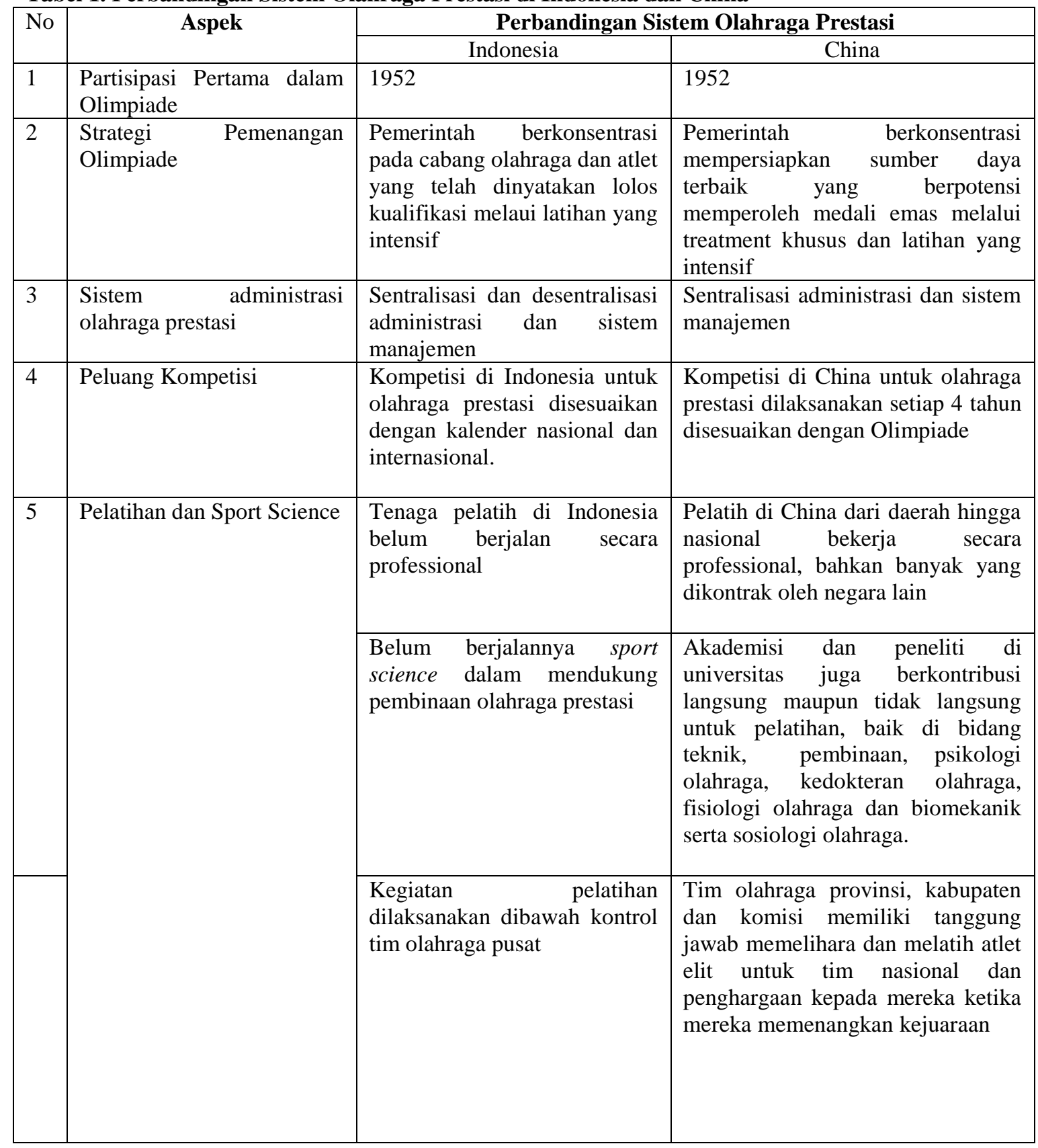

Dipublikasikan Oleh : 


\begin{tabular}{|c|c|c|c|}
\hline 6 & Fasilitas Latihan & $\begin{array}{l}\text { Olahraga prestasi masih } \\
\text { bersifat general untuk cabang } \\
\text { olahraga yang potensial secara } \\
\text { keseluruhan dalam satu pusat } \\
\text { pembinaan }\end{array}$ & $\begin{array}{l}\text { China memiliki pusat-pusat } \\
\text { pembinaan lebih dari } 20 \text { pusat } \\
\text { pembinaan olahraga yang potensial }\end{array}$ \\
\hline 7 & Pemilihan cabang olahraga & $\begin{array}{llr}\text { Cabang } & \text { olahraga } & \text { nasional } \\
\text { sebagian } & \text { besar } & \text { disesuaikan } \\
\text { dengan } & \text { cabang } & \text { olahraga } \\
\text { olimpiade } & \text { dan potensi daerah } \\
\text { yang ada. } & \end{array}$ & $\begin{array}{l}\text { Cabang olahraga nasional sebagian } \\
\text { besar disesuaikan dengan cabang } \\
\text { olimpiade }\end{array}$ \\
\hline \multirow[t]{2}{*}{8} & Persiapan Kompetisi & $\begin{array}{l}\text { Untuk menghadapi Olimpiade } \\
\text { belum terstruktur dalam } \\
\text { program jangka panjang }\end{array}$ & $\begin{array}{l}\text { Untuk menghadapi Olimpiade, } \\
\text { kompetisi tingkat nasional telah } \\
\text { terstruktur dengan baik. }\end{array}$ \\
\hline & & $\begin{array}{l}\text { Fokus kepada cabang olahraga } \\
\text { yang berpotensi menghasilkan } \\
\text { medali }\end{array}$ & $\begin{array}{l}\text { Fokus kepada cabang olahraga yang } \\
\text { dipertandingkan pada Olympiade } \\
\text { baik dari tingkat nasional hingga } \\
\text { internasional, dari tim senior hingga } \\
\text { tim junior. }\end{array}$ \\
\hline
\end{tabular}

Model pengembangan olahraga kompetisi di China mengalami beberapa perubahan fungsi pemerintahan selama 3 tahap antara tahun 1949 dan 2012 pada beberapa bidang (Gu, Wu, Dai, 2015, p. 1353-1357). Pengembangan kebijakan olahraga di China selalu dibentuk oleh persyaratan politik, ekonomi, dan pendidikan. Sejak awal reformasi dan keterbukaan pada akhir tahun 1970-an, olahraga prestasi mendapat lebih banyak dukungan dari pemerintah sementara olahraga masyarakat diharapkan didukung oleh masyarakat itu sendiri.

Secara garis besar tidak banyak perbedaan yang ditemukan dari sistem yang dijalankan di Indonesia dan China. Sama-sama di tahun 1952 sebagai Olimpiade pertama yang diikuti, sistem administrasi yang digunakan juga sama sentralisasi, hanya saja di Indonesia menggabungkan antara sentralisasi dan desentralisasi untuk olahraga prestasi. Peluang kompetisi di Indonesia disesuaikan dengan kalender nasional dan internasional, sedangkan China menyesuaikan dengan kalender Olimpiade, jadi untuk tujuan jangka panjangnya lebih terstruktur dengan baik. Hal ini terlihat pada fokus pemerintah China kepada cabang olahraga yang dipertandingkan pada Olympiade baik dari tingkat nasional hingga internasional, dari tim senior hingga tim junior. Tidak seperti di Indonesia yang hanya memfokuskan pada cabang olahraga atau individu atlet yang sudah

\section{Dipublikasikan Oleh :}


dinyatakan lolos menuju ke Olimpiade. Perbedaan mencolok terlihat pada strategi pemenangan Olimpiade dan fasilitas latihan yang digunakan, serta dukungan sumber daya manusia yang berperan dalam mempersiapkan atlet.

Pemerintah Indonesia berkonsentrasi pada cabang olahraga dan atlet yang telah dinyatakan lolos kualifikasi melalui latihan yang intensif dengan dukungan tenaga pelatih di Indonesia yang belum berjalan secara professional. Mengapa belum professional? Karena banyaknya tenaga pelatih yang masih melakukan hal lain diluar bidang olahraga prestasi, misalnya aktif dalam kepengurusan suatu organisasi, aktif di instansi pemerintahan, dan lain sebagainya. Sedangkan pemerintah China berkonsentrasi mempersiapkan sumber daya terbaik yang berpotensi memperoleh medali emas melalui treatment khusus dan latihan yang intensif yang didukung oleh tenaga pelatihan professional dan tim akademisi serta ilmuwan/ peneliti. Mengapa dikatakan professional? Karena pemerintah memberikan kepercayaan penuh kepada pelatih yang sudah ditunjuk untuk menunjukkan kinerjanya dalam kurun waktu tertentu, dan akan dievaluasi. Oleh karena itu tenaga pelatih bekerja secara professional dan berlomba-lomba untuk dapat menunjukkan hasil yang terbaik dalam peningkatan prestasi olahraga.

Begitupun dengan fasilitas latihan. Fasilitas latihan olahraga prestasi di Indonesia masih bersifat general untuk cabang olahraga yang potensial secara keseluruhan dalam satu pusat pembinaan. Hampir tidak ada perbedaan antara pusat pembinaan tingkat klub, daerah, hingga nasional. Sedangkan fasilitas latihan olahraga prestasi di China dilakukan pada pusat-pusat pembinaan dengan jumlah lebih dari 20 pusat pembinaan olahraga yang potensial.

\section{PENUTUP}

Berdasarkan hasil tinjauan dari delapan aspek yang dianggap berperan besar dalam perkembangan sistem olahraga prestasi di Indonesia dan China, diperoleh kesimpulan bahwa diperlukan kontribusi pemerintah dalam mempersiapkan srategi pemenangan, fasilitas latihan, menambah peluang kompetisi dan peningkatan sumber daya yang bisa dibantu oleh tim akademisi dan peneliti dari universitas untuk menemukan teknik-teknik baru dalam pelatihan untuk menunjang pemanfaatan sport science secara maksimal.

\section{REFERENSI}

Alwasilah, A. C. (2003). Pokoknya Kualitatif. Dasar-Dasar Merancang dan Melakukan Penelitian Kualitatif. Jakarta: Kiblat Buku Utama.

Arikunto, S. (2010). Prosedur Penelitian: Suatu Pendekatan Praktik. Jakarta: Rineka Cipta.

Bennet, B., Howel, M. L., Simri, U. (1983). Comparative Physical Education and Sport. Philadelphia: Lea \& Febiger.

Cholik, T. (2002). Gagasan-Gagasan Tentang Pendidikan Jasmani dan Olahraga. Surabaya: Unesa University Press.

Departemen Pendidikan Nasional. (2004) Olahraga Indonesia dalam Perspektif Sejarah Periode 1945-1965. Jakarta: Proyek Pengembangan dan Keserasian Kebijakan Olahraga. Direktorat Jenderal Olahraga.

G,. D., Wu, Y., \& Dai. Z. (2015). A Study of The Change in Governent Functions in Elite Sport Development in China, 1949-2012. The International Journal of the History of Sport, 32(10), 1353-1357. https://doi.org/10.1080/09523367.2015.1066993

Harsuki. (2012). Pengantar Manajemen Olahraga. Jakarta: Raja Grafindo Persada.

Houlihan, B., Green, M. (2008). Comparative Elite Sport Development. Systems, Structures and Public Policy. Great Britain: Elsevier.

Shodiq, M., Muttaqien, I. (2003). Dasar-Dasar Penelitian Kualitatif. Yogyakarta: Pustaka Pelajar.

Dipublikasikan Oleh : 
Wei, F., Hong, F., \& Zhouxiang, L. (2010). Chinese State Sports Policy: Pre- and Post- Beijing 2008. The International Journal of the History of Sport, 27(14-15), 2380-2402. https://doi.org/10.1080/09523367.2010.504583

Dipublikasikan Oleh : 